\title{
Nasal Cavity and Ethmoid Sinus Cancer pTis TNM Finding v8
}

National Cancer Institute

\section{Source}

National Cancer Institute. Nasal Cavity and Ethmoid Sinus Cancer pT is TNM Finding v8. NCl Thesaurus. Code C133042.

Nasal cavity and ethmoid sinus cancer with a finding of carcinoma in situ. (from AJCC 8th Ed.) 